\title{
Develop Model of Transformational, Transactional Leadership Style, Teachers Perception and Teachers Satisfaction: Evidence from Indonesian High Schools
}

\author{
Widodo Sunaryo ${ }^{1}$, Martinus Tukiran ${ }^{2}$, Nancy Yusnita ${ }^{3}$, Dian Wulandari ${ }^{4}$ \\ 1,2,3,4 Pakuan University, Indonesia. \\ corresponding email : widodos.unpak@yahoo.com
}

\begin{abstract}
This study aims to measure the effect of the principal's leadership style (transformational or transactional) on the job satisfaction of senior high schools in Pati, Central Java, which is mediated by teachers' job perceptions. The data was collected through an electronic questionnaire to 150 teachers in senior high schools. Data processing using SEM method with SmartPLS 3.0 software. The results of this study concluded that transformational leadership has a positive and significant effect on teacher satisfaction, both directly and indirectly through mediating teacher work perceptions. Meanwhile, transactional leadership has no significant effect on teacher satisfaction, either directly or indirectly through mediating teacher work perceptions. This new research proposes a model to build job satisfaction for school teachers in Pati, Central Java through increasing the transformational leadership abilities of principals with perceptions of teacher work as a mediator.
\end{abstract}

Keywords:

Transformational leadership, transactional leadership, job satisfaction, job perception.

Article Received: 18 October 2020, Revised: 3 November 2020, Accepted: 24 December 2020

\section{INTRODUCTION}

According Achmadi (2020) \& Basri (2020) the existence of a leader plays an important role in an organization. The role of a leader is as a direction and goal in the future (direct setter), change agent (change agent), negotiator and as a coach. Studies about leadership is done in various ways, depending on the methodology chosen by the researcher and the definition of leadership. Most of the leadership research includes the traits approach, leader behavior According to Asbari (2020) the existence of a leader plays an important role in an organization. The role of a leader is as a guide and goal in the future (direct setter), change agent, negotiator, and as a coach. Studies about leadership is done in various ways, depending on the methodology chosen by the researcher and the definition of leadership. Most of the leadership research includes the traits approach, leader behavior, power and situational approach . Burns differentiates between transformational leadership and transactional leadership One form of leadership that is believed to be able to balance the thinking patterns and reflection of new paradigms in the current of globalization is defined as transformational leadership. Transformational leadership, described as a leadership style that can arouse or motivate employees, so that they can develop and achieve performance at a high level, more than what they previously thought In addition, transformational leadership styles are considered effective in any situation and culture. According to Bahdin (2020) \& Bernarto (2020).Transformational leadership is described as a leadership style that can arouse or motivate employees so that they can develop and achieve high levels of performance, beyond what they previously thought. Transformational leadership based on conceptual wealth, through charisma, individual considerations and intellectual stimulation, is believed to be able to generate thoughts for future reach, democratic principles and transparency. Therefore it needs to be adopted into the leadership of the principal, especially in 
order to support school-based management or other forms of educational reforms. According to Jannah (2020) ;Nelvitia (2020) \& Sartika (2020) a change in policy direction from centralization to regional autonomy has made schools have a more significant role in determining their own policies in schools that use a school-based management model, the leadership role of the principal in implementing reform efforts in education is very important. Without being accompanied by the leadership of the principal who is aspirational for change, the design of any ideal educational reform effort is unlikely to bring about optimal results. According to Cahyono (2020) \& Pramono (2020) Transformational leadership is considered to be able to answer the challenges of implementing school-based management through three elements, namely charisma and prejudice individual, and intellectual stimulation of the principal. In the context of leadership, it is important for someone to be able to exert influence on others . According to Kadiyono (2020) ; Kartika (2020) \& Fahmi (2020) Transactional leadership is described as leadership that provides an explanation of the responsibilities or duties of subordinates and the rewards they can expect if the specified standards are achieved. This leadership style is open in sharing information and responsibility with subordinates. Although this openness is an important component in running an organization, this leadership is not sufficient to explain the additional effort and performance of subordinates, what a leader can actually extract from his employees. Therefore another concept is needed, so that a leader is able to explore additional efforts or performance from his subordinates. According Achmadi (2020) \& Basri (2020) In transactional leadership, leaders and followers act as bargaining chips in an exchange process that involves rewards and punishments. The main idea of the transactional approach is that there is an exchange, the leader wants what the follower has and in return the leader will give what the follower wants. Thus, transactional leaders motivate subordinates to act as expected through the determination of rewards and punishments.
Transactional leadership has two dimensions which include: (a) Active, the leader monitors and looks for deviations from various rules and standards, and takes corrective action; (b) Passive, leaders intervene only when standards are not achieved .

A number of researchers have investigated the relationship between principal leadership style, teacher satisfaction and performance (Asbari et al., 2020; Purwanto, Bernarto, et al., 2020; Purwanto, Wijayanti, et al., 2019). However, an important factor that has often not been included in previous investigations is the perception of teacher work. This variable includes a number of aspects related to the concept of teaching as a profession, namely professional prestige, professional identification and social status, a sense of self-fulfillment, selfscope, self-development, and work autonomy. The aim of the current study was to examine the effect of two factors on teacher satisfaction from their work, namely the influence of the principal's leadership style (transformational or transactional), teachers' job perceptions about their professional work and their job satisfaction.

\section{LITERATURE REVIEW AND HYPOTHESIS DEVELOPMENT}

Transformational and Transactional Leadership According Achmadi (2020) \& Basri (2020) shows that the form of instructional leadership is in accordance with the world of education, both in the 1980s and 1990s. However, the changes made during the 1990s could not be overcome by the principal's functioning as instructional leaders. The concept of transformational leadership has gradually begun to shift the concept of instructional leadership, as the expectation of the education world for the principal to present a visionary type of leadership into the organization. A mandate difficult for instructional leaders to fulfill. According to Kadiyono (2020) ; Kartika (2020) \& Fahmi (2020) show that principals who are successful in their work have used a variety of mechanisms to motivate and activate their staff to 
bring about change in their school culture. Referring to transformational leadership, Burns (1978) describes their followers and leaders as inspiring each other to achieve " a higher level of morality as well as motivating justice and equality. Meanwhile, the transactional leadership type refers to the exchange relationship between leaders and their followers. Each of them "makes a deal" because of the expectation to fulfill each other's interests and this is the leader's way of maintaining performance by satisfying the needs of followers. (Asbari et al., 2020; Purwanto, Asbari, et al., 2019) indicate that transformational leadership binds leaders and followers in a collaborative process and thus contributes to the performance of the entire organization. Transactional leadership, meanwhile, does not bind leaders and followers in any way of collaboration. Therefore, this type of leadership results in a routine, uncreative but stable organizational environment. In contrast to transformational leadership which requires a responsive attitude and an innovative environment. The perception of this leadership style contains an assessment that transformational leadership is described as more beneficial than transactional leadership. According to Cahyono (2020) \& Pramono (2020) The leader's ability to pay personal attention to followers, while intellectual stimulation is the leader's ability to motivate followers to think innovative and unusual solutions to various problems at hand. Later, Bass and Avolio (1990) added another factor, namely inspiration to describe transformational leadership. Even so, the ability to inspire is considered closely related to charisma and because it is often seen as the same constituent. According to Jannah (2020) ;Nelvitia (2020) \& Sartika (2020) identified six main characteristics of transformational educational leaders, namely building a school's vision and goals, providing intellectual stimulation, offering individualized support, symbolizing professional practices and values, showing high performance expectations, and developing structures to foster participation in school decisions. Contingent reward, one subfactor of transactional leadership, relates to a situation in which a leader rewards followers for completing the agreed task. Management by exception is another subfactor that describes transactional leadership, relating to situations where the leader only responds in cases when there is a problem. Then, This factor is as contained in two forms: passive and active. According to Bahdin (2020) \& Bernarto (2020).With regard to educational settings, transactional leadership has been described as having four dimensions, namely teaching, instructional support, monitoring school activities, and community focus

\section{Teacher Job Satisfaction}

The mission of education seems to depend on how teachers feel about their job and how satisfied they are with it. Therefore, it is not surprising that researchers suggest that schools should pay more attention to increasing teacher job satisfaction , motivation factors and hygiene factors. Herzberg's Two-Factor Theory identified that motivation factors are related to psychological needs. This need includes a series of intrinsic conditions, job satisfaction (job content) which, if present in the job, will drive a strong level of motivation, which can result in achievement. According to Kadiyono (2020) ; Kartika (2020) \& Fahmi (2020) motivation factors are related to personal appreciation that is directly related to work. This factor is called satisfiers, which includes achievement, recognition, work itself, responsibility, and opportunities to develop. Meanwhile, the hygiene factor or maintenance factor is a maintenance factor related to human nature who wants to get physical peace. According to Jannah (2020) ;Nelvitia (2020) \& Sartika (2020), this health need is an ongoing need, because this need will return to zero after being met. This factor is related to work extrinsic matters, such as working conditions, supervision, work policies, salaries, and interpersonal relationships

According to Vizano (2020) ;Sena (2020) \& 
Nugroho (2020) The extensive literature supports the claim that job satisfaction is positive associated with participatory decision making and transformational leadership. Overall, teachers reported greater satisfaction in their work when they viewed their principal as someone who shared information with others, delegated authority, and maintained open communication with teachers. According to Cahyono (2020) \& Pramono (2020) Teacher satisfaction is also associated with greater autonomy in the workplace and with other aspects of others related to the teaching profession. According to Kadiyono (2020) ; Kartika (2020) \& Fahmi (2020) found that teachers were reported that they chose jobs because of their inherent professional values expressed higher levels of satisfaction and greater commitment than their peers who went to teach for economic reasons. According to Bahdin (2020) \& Bernarto (2020). revealed that teachers are planning to leave the profession expressed less job satisfaction and more negative attitudes toward teaching as his career. According to Vizano (2020) ;Sena (2020) \& Nugroho (2020) Teacher job satisfaction is also related to teacher retention through various aspects such as satisfaction with the leadership of the principal and satisfaction in general Purwanto (2020) found that teacher job satisfaction is a determinant of teacher commitment and that it must exist before individuals provide organizational commitment. Teachers derive job satisfaction from their relationship with current and previous students, the teacher's relationship with parents and colleagues , Kadiyono (2020) ; Kartika (2020) \& Fahmi (2020) also found that interpersonal relationships were among the main sources of teacher satisfaction, whereas sources of teacher job dissatisfaction were related to structural and administrative factors. Another indication for its importance The teacher-student relationship is found in According to Nugroho (2020) ; Nico (2020) \& Yunita (2020) study, which is revealing that the most effective teachers place great emphasis on the student-teacher relationship. According to Nugroho (2020) ; Nico (2020) \&
Yunita (2020) concluded that the teacher-student relationship was the most important and reported a more satisfied relationship with aspects of their work than others. Knowing their students are achieving achievements and watching them learn from their experiences, in addition to using the skills they have acquired, are a major source of job satisfaction among teachers. Student achievement was identified as a very important source of teacher satisfaction, according to the interesting findings of the study.

\section{Perceptions of Teacher Work}

The term teacher job perception refers primarily to the intrinsic and extrinsic dimensions of teacher work. Intrinsic nature relates to aspects of teaching such as autonomy in the workplace), professional pride and status, personal development, and selfesteem. Extrinsic nature refers to the physical aspects of the workplace and its benefits (eg salary). Obviously, both types of aspects relate to problems related to teaching work as a profession. With respect to teacher job satisfaction, it is hypothesized that the teacher job description is one that confer high status, good individual promotion opportunities, possibilities for selfdevelopment, and personal growth (among others ) will positively influence their job satisfaction measures. According Achmadi (2020) \& Basri (2020) satisfiers were responsible for achievement, recognition, and responsibility and dissatifiers including interpersonal relationships with peers and subordinates, supervision (technical), and school policy. In a study examining the effects of leader behavior, it was found that job status is an important factor in predicting satisfactionThe effect of perceptions of teacher autonomy in the classroom was also examined and found to be positively correlated with job satisfaction. Teacher empowerment is another aspect of the perception of the range of their work. It refers to professional growth, autonomy, self-efficacy, impact (teachers' perceptions of their ability to influence school performance), professional rewards, and 
involvement in that decision directly affects their work . According to Bahdin (2020) \& Bernarto (2020) found a positive relationship between the instructional leadership behavior of principals, quality of teaching, learning and professional engagement. Professional engagement is here defined as the degree to which teachers feel involved about their work, want to learn from each other, and are committed to professional development. According to Cahyono (2020) \& Pramono (2020) found that teachers are most satisfied with matters intrinsic to their work, such as self-growth, mastery of professional skills, and a supportive environment. These findings imply that teachers highly value the professional aspects of their jobs.

Based on the theoretical study and previous research above, the research model of research hypothesis is as follows:

H1: Transformational leadership has a significant effect on teacher job satisfaction

H2: Transactional leadership has a significant effect on teacher job satisfaction

H3: Transformational leadership has a significant effect on teacher perceptions of work

H4: Transaction leadership has a significant effect on teacher work perceptions

H5: Teacher job perceptions have a significant effect on teacher job satisfaction

H6: Transformational leadership has a significant effect on teacher job satisfaction through mediating teacher work perceptions

H7: Transactional leadership has a significant effect on teacher job satisfaction through mediating teacher work perceptions

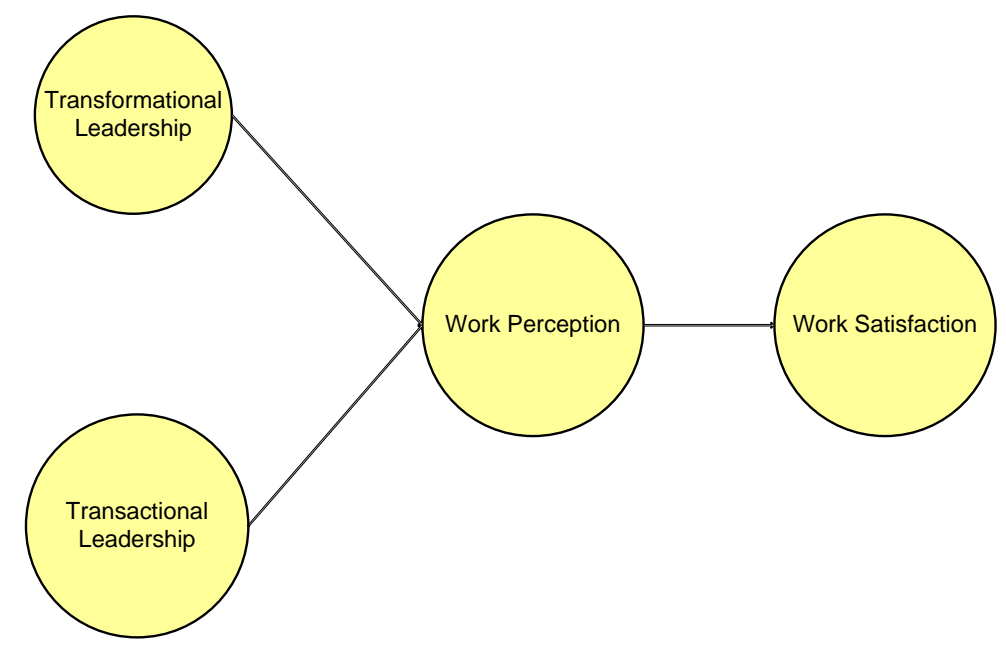

Fig 1. Research Model

\section{METHOD}

The method used in this research is a quantitative method. Data collection is carried out by circulating the team to all teachers of the school education institution. The instrument used to measure all the variables of this study was adapted from with 5 items of each variable. This quantitative analysis is similar conducted by Achmadi (2020) ; Basri (2020) ; Bahdin (2020) ; Bernarto (2020); Cahyono (2020) ; Pramono (2020); Kadiyono (2020) ; Kartika (2020) ; Fahmi (2020) ; Jannah (2020) ;Nelvitia (2020) ; Sartika (2020) ; Vizano (2020) ;Sena (2020) ; Nugroho
(2020) ; Nugroho (2020) ; Nico (2020) \& Yunita (2020) ; Purwanto (2020) \& Ardi (2020)The questionnaire is designed closed except for questions / statements regarding the identity of the respondent in the form of a semi-open questionnaire. Each closed question / statement item is given five answer options, namely: strongly agree (SS) score 5, agree (S) score 4, disagree (KS) score 3, disagree (TS) score 2, and strongly disagree (STS) ) score 1. The method for processing data is by using PLS and using SmartPLS version 3.0 software as a tool. The population in this study were senior high school 
teachers whose number had not been identified with certainty. The questionnaire was distributed electronically using simple random sampling technique. The results of the questionnaire returned were 150 respondents.

Table 1. Respondents Profile

\begin{tabular}{ccc}
\hline & Criteria & Total \\
\hline Age & $<30$ year & 50 \\
& $30-40$ year & 64 \\
& $>40$ year & 36 \\
\hline Gender & Male & 100 \\
& Female & 50 \\
\hline Work Experience & $<5$ Year & 54 \\
& $5-10$ Year & 46 \\
& $>10$ Year & 50 \\
\hline Education & Bachelor Degree & 132 \\
& Master Degree & 18 \\
\hline
\end{tabular}

\section{RESULT AND DISCUSSION}

The testing phase of the measurement model includes testing for convergent validity, discriminant validity and composite reliability. The results of the PLS analysis can be used to test the research hypothesis if all indicators in the PLS model have met the requirements of convergent validity, discriminant validity and reliability testing. Convergent validity test is done by looking at the loading factor value of each indicator against the construct. In most references, a factor weight of 0.5 or more is considered to have sufficiently strong validation to explain latent constructs (Chin, 1998; Hair et al, 2010; Ghozali, 2014). This Similar research conducted by Achmadi (2020) ; Basri (2020) ; Bahdin (2020) ;
Bernarto (2020); Cahyono (2020) ; Pramono (2020); Kadiyono (2020) In this study, the minimum limit for the accepted loading factor is 0.5 , provided that the AVE value of each construct is> 0.5 (Ghozali, 2014). All indicators have a loading factor value above 0.5 so that the model has met the convergent validity requirements. Apart from looking at the loading factor value of each indicator, convergent validity was also assessed from the AVE value of each construct. The AVE value for each construct of this study is above 0.5 . So the convergent validity of this research model has met the requirements. The value of loadings, cronbach's alpha, composite reliability and AVE for each complete construct can be seen in table 2 below:

Table 2: Items Loadings, Cronbach's Alpha, Composite Reliability, and Average Variance Extracted (AVE)

\begin{tabular}{cccccc}
\hline & Items & Loadings & $\begin{array}{c}\text { Cronbach's } \\
\text { Alpha }\end{array}$ & $\begin{array}{c}\text { Composite } \\
\text { Reliability }\end{array}$ & AVE \\
\hline \multirow{2}{*}{ Transformational } & TL1 & 0.643 & 0.865 & 0.898 & 0.645 \\
(TL) & TL2 & 0.731 & & & \\
& TL3 & 0.678 & & & \\
& TL4 & 0.786 & & & \\
& TL5 & 0.567 & & & \\
Transactional & TS1 & 0.765 & 0.878 & 0.867 &
\end{tabular}




\begin{tabular}{cccccc} 
(TS) & TS3 & 0.876 & & & \\
& TS4 & 0.675 & & & \\
& TS5 & 0.654 & & & \\
\hline Work Perception & PK1 & 0.675 & 0.945 & 0.978 & 0.764 \\
(PK) & PK2 & 0.765 & & & \\
& PK3 & 0.567 & & & \\
& PK4 & 0.765 & & & \\
& PK5 & 0.765 & & 0.856 \\
Work Satisfaction & KK1 & 0.676 & 0.956 & & \\
(KK) & KK2 & 0.548 & & & \\
& KK3 & 0.678 & & & \\
& KK4 & 0.678 & & & \\
& KK5 & 0.787 & & & \\
\hline
\end{tabular}

Discriminant validity is done to ensure that each concept of each latent variable is different from other latent variables. The model has good discriminant validity if the AVE squared value of each exogenous construct (the value on the diagonal) exceeds the correlation between this construct and other constructs (values below the diagonal) (Ghozali, 2014). The results of discriminant validity testing using the AVE square value, namely by looking at the Fornell-Larcker Criterion Value are obtained as follows:

Table 3. Discriminant Validity

\begin{tabular}{ccccc}
\hline Variables & KK & PK & TL & TS \\
\hline KK & $\mathbf{0 . 8 9 8}$ & & & \\
PK & 0.772 & $\mathbf{0 . 8 4 5}$ & & \\
TL & 0.736 & 0.781 & $\mathbf{0 . 7 8 6}$ & \\
TS & 0.303 & 0.330 & 0.471 & $\mathbf{0 . 7 9 7}$ \\
\hline
\end{tabular}

The results of the discriminant validity test in table 2 above show that all constructs have a square root value of AVE above the correlation value with other latent constructs (through Fornell-Larcker criteria) so that it can be concluded that the model has met discriminant validity. Construct reliability can be assessed from the Cronbach's alpha value and the composite reliability of each construct. This Similar research conducted by Kartika (2020) ; Fahmi (2020) ; Jannah (2020) ;Nelvitia (2020) ; Sartika (2020) ; Vizano (2020) ;Sena (2020) ; Nugroho (2020); Nugroho (2020) ; Nico (2020) \& Yunita (2020); Purwanto (2020) \& Ardi (2020) The recommended composite reliability and cronbach's alpha value is more than 0.7. (Ghozali, 2014). The reliability test results in Table 2 above show that all constructs have composite reliability and Cronbach's alpha values are greater than 0.7 (> 0.7). In conclusion, all constructs have met the required reliability.

Hypothesis testing in PLS is also called the inner model test. This test includes a significance test for direct and indirect effects as well as measuring the magnitude of the influence of exogenous variables on endogenous variables. To determine the effect of transformational leadership and transactional leadership on teacher job perceptions and teacher job satisfaction, a direct and indirect effect test is needed. The effect test was carried out using the t-statistical test in the partial least squared (PLS) analysis model using the SmartPLS 3.0 software. With the boothstrapping technique, the R Square value and significance test values are 
obtained as shown in the table below:

Table 4. $R$ Square Value

\begin{tabular}{ccc}
\hline & R Square & R Square Adjusted \\
\hline KK & 0.624 & 0.684 \\
PK & 0.621 & 0.690 \\
\hline
\end{tabular}

Tabel 5 Hypotheses Testing

\begin{tabular}{|c|c|c|c|c|c|c|}
\hline Hypotheses & Relationship & Beta & SE & $\begin{array}{c}\mathbf{T} \\
\text { Statistics }\end{array}$ & $\begin{array}{c}\text { P- } \\
\text { Values }\end{array}$ & Decision \\
\hline H1 & TL ->KK & 0.306 & 0.086 & 5.278 & 0.000 & Supported \\
\hline $\mathrm{H} 2$ & $\mathrm{TS}->\mathrm{KK}$ & -0.023 & 0.083 & 0.804 & 0.420 & $\begin{array}{c}\text { Not } \\
\text { Supported }\end{array}$ \\
\hline H3 & TL $->P K$ & 0.840 & 0.053 & 23.511 & 0.000 & Supported \\
\hline $\mathrm{H} 4$ & $\mathrm{TS}->\mathrm{PK}$ & -0.094 & 0.005 & 0.957 & 0.330 & $\begin{array}{c}\text { Not } \\
\text { Supported }\end{array}$ \\
\hline $\mathrm{H} 5$ & $\mathrm{PK}->\mathrm{KK}$ & 0.510 & 0.036 & 7.878 & 0.000 & Supported \\
\hline H6 & $\mathrm{TL}->\mathrm{PK}->\mathrm{KK}$ & 0.430 & 0.085 & 6.929 & 0.000 & Supported \\
\hline $\mathrm{H} 7$ & $\mathrm{TS}->\mathrm{PK}->\mathrm{KK}$ & -0.025 & 0.025 & 0.917 & 0.323 & $\begin{array}{c}\text { Not } \\
\text { Supported }\end{array}$ \\
\hline
\end{tabular}

Based on Table 4 above, the $\mathrm{R}$ SquarePK value is 0.621 , which means that the variable job perception (PK) can be explained by the transformational leadership (TL) and transactional leadership (TS) variables of $62.1 \%$, while the remaining $37.9 \%$ is explained by other variables that are not discussed in this study. Meanwhile, the R Square KK value of 0.624 means that the variable teacher job satisfaction $(\mathrm{KK})$ can be explained by the transformational leadership (TL), transactional leadership (TS) and work perception (PK) variables by $62.4 \%$, while the remaining $37.6 \%$ is explained by other variables not discussed in this study. Meanwhile, Table 5 shows the $\mathrm{T}$ Statistics and P-Values which show the influence between the research variables that have been mentioned. In summary, transformational leadership has a positive and significant effect on job satisfaction, both directly and through work perception media. So H1, H3, H5 and H6 are accepted. Meanwhile, transactional leadership has no significant effect on teacher job satisfaction, either directly or through mediating teacher work perceptions. So $\mathrm{H} 2, \mathrm{H} 4$, and $\mathrm{H} 7$ are rejected. This result is align with Achmadi (2020) ; Basri (2020) ; Bahdin (2020) ; Bernarto (2020); Cahyono (2020) ; Pramono (2020); Kadiyono (2020) ; Kartika (2020) ; Fahmi (2020) ; Jannah (2020) ;Nelvitia (2020) ; Sartika (2020) ; Vizano (2020) ;Sena (2020) ; Nugroho (2020) ; Nugroho (2020) ; Nico (2020) \& Yunita (2020) ; Purwanto (2020) $\&$ Ardi (2020)

The most interesting finding from this study is the effect of teacher perceptions on their job satisfaction. They have perceptions of job prestige, 
self-esteem, autonomy at work, and professional self-development that contribute the most to job satisfaction. These findings support previous research which revealed a significant positive relationship between aspects of teaching work and job satisfaction (Asbari, Bernarto, et al., 2020; Purwanto, Mayesti Wijayanti, et al., 2019). This variable serves as an intermediary variable for the principal's leadership style and teacher satisfaction. According to Kadiyono (2020) ; Kartika (2020) \& Fahmi (2020) teachers reported feeling very satisfied when their work gave them a "sense of self-worth," gave them "opportunities for self-development," gave them "feelings of success," and enabled them "to participate in determining teaching and learning practices in schools. Expressions of such feelings about their job support theories of teacher job satisfaction, such as the two-factor theory derived from the work of Achmadi (2020) \& Basri (2020) These researchers argue that motivators, which refer to intrinsic aspects of teaching such as teachers' selfgrowth, personal development, and recognition, tends to promote job satisfaction. Cleanliness factors, which are associated with external aspects of the job as poor working conditions, are likely to cause teacher dissatisfaction (Asbari, Nurhayati, et al., 2020; Bernarto et al., 2020; Hyun et al., 2020; ; Purwanto, Mayesti Wijayanti, et al., 2019; Purwanto, Putri, et al., 2020). The next study should investigate the concept of teacher job satisfaction by differentiating its constituents, as has been done in many studies. In the current study, overall job satisfaction, including the aspect of fulfillment itself with both the internal and physical aspects of the work is examined Further research should be carried out u To clarify the concept of job satisfaction because as reported by (Hyun et al., 2020), there is heterogeneity between teachers with respect to what they consider satisfactory or satisfying.

\section{CONCLUSION}

The implications and conclusions of these findings support research conducted elsewhere, such as research (Fayzhall et al., 2020; Asbari et al., 2020;
Purwanto, Asbari, et al., 2020; Purwanto, Bernarto, et al., 2020; Purwanto, Wijayanti, et al., 2019) who show that teachers prefer to work with principals who exhibit transformational rather than transactional types of behavior. (However, this finding should not be surprising because actors who act as transformational leaders seem to maximize the autonomy that has long been lacking. Given that the challenge to education is more in the area of how teachers can better coordinate their work than how they can maximize their autonomy The findings regarding teacher preferences for transformational school heads seem to strengthen organizational structure and function. in order to increase To increase the satisfaction level of workplace teachers, school management needs to pay attention to factors related to all aspects of teaching and learning, especially those entitled "professional," as they refer to the characteristics of teaching as a vocation. Teachers' perceptions of work from data collection were very significant in influencing their satisfaction. This implication should be recognized by top level decision makers, such as government officials, and at a more local level, by supervisors and school principals. The more teachers view their teaching work as their profession and center of life, the more satisfied they will be. Moreover, to increase the general feelings of all teachers, principals need to be more aware of how strongly their roles and behaviors influence teachers' perceptions of management and their job satisfaction. Through transformational leadership and participatory behavior, principals can develop and cultivate positive feelings and attitudes of teachers about their noble work. Understanding that teaching as a job that gives a sense of value and professional prestige will make teachers see it as central to their lives and thereby increase their job satisfaction Teacher satisfaction from work is very important to good relationships between teachers and students, because teachers who are satisfied will be more enthusiastic about investing. time and energy in teaching their students. Hence, this study may provide the first step in a research line linking 
principals to teachers and with students. Further research on this can be achieved through collecting data from principals about their leadership styles, decision-making approaches, demographics and how these variables affect teacher views. about job satisfaction and ultimately have a positive impact on students' competencies and their learning performance.

\section{REFERENCES}

[1] Asbari, M., Bernarto, I., Pramono, R., Purwanto, A., Hidayat, D., Sopa, A., Alamsyah, V. U., Senjaya, P., Fayzhall, M., \& Mustofa. (2020). The effect of work-family conflict on job satisfaction and performance: A study of Indonesian female employees. International Journal of Advanced Science and Technology, 29(3), 6724-6748.

[2] Asbari, M., Santoso, P.B. and Purwanto, A. (2019). Influence of Leadership, Motivation, Competence, Commitment and Culture on ISO 9001:2015 Performance in Packaging Industry. Scholars Journal of Economics, Business and Management. 6(12): 577-582. DOI: http://doi.org/10.36347/sjebm.2019.v06i12 .005 .

[3] Asbari, M., Wijayanti, L.M., Hyun, C.C., Purwanto, A., Santoso, P.B., Bernarto, I., Pramono, R., and Fayzhall, M. (2020). The Role of Knowledge Transfer and Organizational Learning to Build Innovation Capability: Evidence from Indonesian Automotive Industry. International Journal of Control and Automation. 13(1): 19-322. Link: http://sersc.org/journals/index.php/IJCA/ar ticle/view/5732

[4] Purwanto, A., Asbari, M., \& Santoso, P. B. (2019). Influence of Transformational and Transactional Leadership Style toward Food Safety Management System ISO 22000:2018 Performance of Food Industry in Pati Central Java. Inovbiz: Jurnal
Inovasi Bisnis,

$7(2)$, 180. https://doi.org/10.35314/inovbiz.v7i2.1213

[5] Purwanto, A., Asbari, M., and Santoso, P.B. (2019). Does Culture, Motivation, Competence, Leadership, Commitment Influence Quality Performance? Jurnal Inovasi Bisnis. 6(2): 201-205. DOI: https://doi.org/10.35314/inovbiz.v7i2.1210

[6] Purwanto, A., Asbari, M., and Santoso, P.B. (2019). Influence of Transformational and Transactional Leadership Style toward Food Safety Management System ISO 22000:2018 Performance of Food Industry in Pati Central Java. Jurnal Inovasi Bisnis. 6(2): 180-185. DOI: https://doi.org/10.35314/inovbiz.v7i2.1213 $\dot{-}$

[7] Purwanto, A., Asbari, M., and Santoso, P.B. (2019). Pengaruh Kompetensi, Motivasi, Kepemimpinan, Komitmen

[8] Reyes, P., \& Shin, H. S. (1995). Teachercommitment and job satisfaction: A causal analysis. Journal of School Leadership, 5(1), 22-39.

[9] Rice, E. M.,\&Schneider, G. T. (1994). A decade of teacher empowerment: An empirical analysis of teacherin volvement in decision making, 1980-1991. Journal of Educational Administration, 32(1), 43-58.

[10] Rossmiller, R. A. (1992). The secondary school principal and teachers'quality ofwork life. Educational Management and Administration, 20(3), 132-146.

[11] Schneider, G. T. (1984). Teacher involvement in decision making zones of acceptance, decision conditions, and job satisfaction. Journal of Research and Development in Education, 18(1), 25-32.

[12] Sergiovanni, T. (1967). Factors which affect satisfaction and dissatisfaction of teachers. Journal of Educational Administration, 5(1), 66-81. 
[13] Shann, M. H. (1998). Professional commitment and satisfaction among teachers in urban middle schools. Journal of Educational Research, 92(2), 67-73.

[14] Sheppard, B. (1996). Exploring the transformational nature of instructional leadership. Alberta Journal of Educational Research, 42(4), 325-344.

[15] Silins, H. C. (1992). Effective leadership for school reform. Alberta Journal of Educational Research, 38(4), 317-334.

[16] Silins, H. C. (1994). The relationship between transformational and transactional leadership and school improvement outcomes. School Effectiveness and School Improvement, 5(3), 272-298.

[17] Spector, P. E. (1997). Job satisfaction. Thousand Oaks, CA: Sage.

[18] Taylor, D., \& Tashakkori, A. (1995). Decision participation and school climate as predictors of job satisfaction and teachers'sense of efficacy. Journal of Experimental Education, 63, 217-230.

[19] Tepper, B. J., \& Percy, P. M. (1994). Structural validity of the Multifactor Leadership Q Abidina, Z., Heddyb, ., Astutic, . Y. G. A., Adhad, . S., Asrorie, . K., Subrotof, . D. E., Zaharag, . V. M., Kahpih, . H. S., Purwantoi, . A., Julyantoj, . O. \&Azizik, . E. (2020) Effect of Transformational and Transactional Leadership TowardIso 22000:2018 Food Safety Certified Company Performance. Systematic Reviews in Pharmacy, 11 (7), 529-538. doi:10.31838/srp.2020.7.77

[20] Achmadi, H., Antonio, . F., Pramono, . R., Bernarto, . I. \& Purwanto, . A. (2020) Identification of The Positive and Negative Emotions that Appeared among High School Students When Selecting Business at Jakarta and Surrounding Area. Systematic Reviews in Pharmacy, 11 (9), 759-766. doi:10.31838/srp.2020.9.107
[21] Basri, ., Wibowo, . T. S., Abdillah, . A., Kharis, . A., Jaenudin, ., Purwanto, . A., Mufid, . A., Maharani, . S., Badi ati, . A. Q., Fahlevi, . M. \&Sumartiningsih, . S. (2020) Democratic, Authocratic, Bureaucratic and Charismatic Leadership Style: Which Influence School Teachers Performance in Education 4.0 Era?. Systematic Reviews in Pharmacy, 11 (9), 277-286. doi:10.31838/srp.2020.9.45

[22] BahdinNurTanjunga, YurniRahmanb, Budiyantoc, Badawid, Aep Tata Suryanae, Warni Tune Sumarf, Abdul Mufidg, Agus Purwantoh, Wartoi (2020) The Influence of Transformational Leadership, Job Satisfaction and Organizational Citizenship Behavior on the Performance of Islamic School Teachers. Systematic Reviews in Pharmacy, $11 \quad$ (7), 539-546. doi:10.31838/srp.2020.7.78

[23] Bernardin, H. John, and Joyce, E. A. Russel. 1993. Human Resoure Management AnExpreriential Approach. New York: McGraw - Hill. Series In Management

[24] Bernarto, Diana Bachtiar, NikoSudibjo, Ian NurpatriaSuryawan, Agus Purwanto, MasdukiAsbari.(2020). Effect of Transformational Leadership, Perceived Organizational Support, Job Satisfaction Toward Life Satisfaction: Evidences from Indonesian Teachers. International Journal of Advanced Science and Technology.29(3). 5495 -5503

[25] Christine, W.S., Oktorina, Megawati, danMula, Indah. 2010. "PengaruhKonflikPekerjaandanKonflikKel uargasebagaiInterverningVariabel

(Studipada Dual Career. Couple di Jabotabek)".

JurnalManagemendanKewirausahaan, Volume 12 No. 2. Hal 121-132 Jakarta Selatan :UniversitasKatolik Indonesia Atina Jaya 
[26] Cahyono, Y., Jihadi, . M., Arifin, . Z., Purnamasari, . W., Musnaini, ., Wijoyo, . H., Fitriaty, ., Putra, . R. S., Putri, . R. A., Muliansyah, . D., Suryani, . P. \& Purwanto, . A. (2020) Do Servant Leadership Influence Market Performance? Evidence from Indonesian Pharmacy Industries. Systematic Reviews in Pharmacy, $11 \quad$ (9), 439-451. doi:10.31838/srp.2020.9.62

[27] Suheny, . E., Arum, . M., Wandi, . D., Rahmat, . A., kurnianingsih, . A., Haerani, . A., Dasmaran, . V., Taryanto, ., Adha, . S. \& Purwanto, . A. (2020) Develop Leadership Style Model for Indonesian SMEs Leaders During Covid-19 Pandemic. Systematic Reviews in Pharmacy, 11 (8), 576-586. doi:10.31838/srp.2020.8.82

[28] Pramono,R.Kristianti,T.,Purwanto, A. (2020).Character Development Training for Adults (A Case Study of Heartmaster Program in Jakarta). Test Engineering \& Management. $\quad 83.5809 \quad-581$. http://www.testmagzine.biz/index.php/test magzine/article/view/4556

[29] Supriadi, O., Musthan, . Z., Saodah, ., Nurjehan, . R., Haryanti, . Y. D., Marwal, . M. R., Purwanto, . A., Mufid, . A., Yulianto, . R. A., Farhan, . M., Fitri, . A. A., Fahlevi, . M. \&Sumartiningsih, . S. (2020) Did Transformational, Transactional Leadership Style and Organizational Learning Influence Innovation Capabilities of School Teachers during Covid-19 Pandemic?. Systematic Reviews in Pharmacy, 11 (9), 299-311. doi:10.31838/srp.2020.9.47

[30] Kadiyono, A. L., Sulistiobudi, . R. A., Haris, . I., Wahab, . M. K. A., Ramdani, . I., Purwanto, . A., Mufid, . A., Muqtada, . M. R., Gufron, . M., Nuryansah, . M., Ficayuma, . L. A., Fahlevi, . M. \&Sumartiningsih, . S. (2020) Develop Leadership Style Model for Indonesian
Teachers Performance in Education 4.0 Era. Systematic Reviews in Pharmacy, 11 (9), 363-373.doi:10.31838/srp.2020.9.52

[31] TeguhSetiawanWibowoa,

AlfiQonitaBadiatib, ArnaAsnaAnnisac, MohdKhaidir Abdul Wahabd, M. RifaJamaludine, MuhamadRozikanf, Abdul Mufidg, KhaerulFahmih, Agus Purwantoi, AkhmadMuhainij (2020) Effect of Hard Skills, Soft Skills, Organizational Learning and Innovation Capability on Islamic Business Lecturers' Performance. Systematic Reviews in Pharmacy, 11 (7), 556-569. doi:10.31838/srp.2020.7.80

[32] N. E., Roswandi, . I., Rahim, . A., Naro, . A., Izzati, . T., Munita, . A. A., Junaedi, . D., Suprihatiningsih, . W., Purwanto, . A. \&Bakti, . C. S. (2020) Six Sigma Benefit for Indonesian Pharmaceutical Industries Performance: A Quantitative Methods Approach. Systematic Reviews in Pharmacy, $11 \quad$ (9), 466-473. doi:10.31838/srp.2020.9.66

[33] Cahyono, Y., Jihadi, . M., Arifin, . Z., Purnamasari,. W., Musnaini, ., Wijoyo, . H., Fitriaty, ., Putra, . R. S., Putri, . R. A., Muliansyah, . D., Suryani, . P. \& Purwanto, . A. (2020) Do Servant Leadership Influence Market Performance? Evidence from Indonesian Pharmacy Industries. Systematic Reviews in Pharmacy, $11 \quad$ (9), 439-451. doi:10.31838/srp.2020.9.62

[34] Kartika, H., Norita, . D., Triana, . N. E., Roswandi, . I., Rahim, . A., Naro, . A., Izzati, . T., Munita, . A. A., Junaedi, . D., Suprihatiningsih, . W., Purwanto, . A. \& Bakti, . C. S. (2020) Six Sigma Benefit for Indonesian Pharmaceutical Industries Performance: A Quantitative Methods Approach. Systematic Reviews in Pharmacy, $11 \quad$ (9), 466-473. doi:10.31838/srp.2020.9.66 
[35] Fahmi, K., Kurniawan, . T., Cahyono, . Y., Sena, . A., Suhadarliyah, ., Suryani, . P., Sugianto, . A., Amelia, . D., Musnaini, ., Amin, . S., Hasbullah, . H., Jihadi, . M., Wijoyo, . H. \& Purwanto, . A. (2020) Did Servant, Digital and Green Leadership Influence Market Performance? Evidence from Indonesian Pharmaceutical Industry. Systematic Reviews in Pharmacy, 11 (9), 642-653. doi:10.31838/srp.2020.9.95

[36] Jannah, M., Fahlevi, . M., Paulina, . J., Nugroho, . B. S., Purwanto, . A., Subarkah, . M. A., Kurniati, . E., Wibowo, . T. S., Kasbuntoro, ., Kalbuana, . N. \&Cahyono, . Y. (2020) Effect of ISO 9001, ISO 45001 and ISO 14000 toward Financial Performance of Indonesian Manufacturing. Systematic Reviews in Pharmacy, 11 (10), 894-902. doi:10.31838/srp.2020.10.134

[37] NelvitiaPurba, Ali MuktiTanjung, Sri Sulistyawati, Rudy Pramono and Agus Purwanto.(2020). Death Penalty and Human Rights in Indonesia, International Journal of Criminology and Sociology, 9(2020), 1356-1362, DOI: https://doi.org/10.6000/19294409.2020.09.156

[38] Sartika, . N. S., Subroto, . D. E., Mauladaniyati, . R., Rosdianwinata, . E., Rifai, . R., Sujana, . A., Abidin, . Z., Priadi, . M. D., Setiawati, . E., Yanti, . D. \& Purwanto, . A. (2020) Effect of Pedagogic, Professional Competency, and Work Motivation Toward Indonesian Primary School Teachers Performance. Systematic Reviews in Pharmacy, 11 (9), 617-626. doi:10.31838/srp.2020.9.91

[39] Vizano, N. A., Utami, . W., Johanes, . S., Herawati, . A., Aima, . H., Sutawijaya, . A. H., Purwanto, . A., Supono, . J., Rahayu, . P., Setiyani, . A., Widayati, . C. C. \& Elmi, . F. (2020) Effect of Career, Organizational Commitment on Turnover Intention through Mediation of Organizational
Culture: Evidence from Indonesian Companies. Systematic Reviews in $\begin{array}{llll}\text { Pharmacy, } & 11 & \text { (9), 931-937. }\end{array}$ doi:10.31838/srp.2020.9.136

[40] Sena, A., Cahyono, . Y. \& Purwanto, . A. (2020) The Influence of Organizational Culture, Job Satisfaction, and Professional Commitment on Innovative Behavior of Flight Instructors at the Civil Flight School in Indonesia. Systematic Reviews in

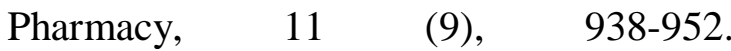
doi:10.31838/srp.2020.9.137

[41] Nugroho, B. S., Widdah, . M. E., Hakim, . L., Nashirudin, . M., Nurlaeli, . A., Purnomo, . J. H., Aziz, . M., Adinugraha, . H. H., Sartika, . M., Fikri, . M. K., Mufid, . A., Purwanto, . A. \& Fahlevi, . M. (2020) Effect of Organizational Citizenship Behavior, Work Satisfaction and Organizational Commitment toward Indonesian School Performance. Systematic Reviews in Pharmacy, 11 (9), 962-971. doi:10.31838/srp.2020.9.140

[42] Nugroho, B. S., Suheri, ., Hakim, . L., Irawan, . B., Sholehuddin, . M. S., Ibrahim, . T., Ridlwan, . M., Hidayati, . L., Aji, . G., Mufid, . A., Ihsan, . N., Purwanto, . A. \& Fahlevi, . M. (2020) Effect of Knowledge Sharing dan Leader member Exchange (LMX) and Organizational Citizenship Behavior (OCB) to Indonesian Lectures' Performance. Systematic Reviews in $\begin{array}{llll}\text { Pharmacy, } & 11 & \text { (9), } & \text { 972-981. }\end{array}$ doi:10.31838/srp.2020.9.141

[43] Nico Alexander Vizano, AnisFittria, MohamadNuryansah, Muhammad RikzaMuqtada, Gufron , MohFarhan, Agus Purwanto (2020). HALAL MEDICINE PURCHASE INTENTION AMONG SOUTH EAST ASIAN CONSUMERS. European Journal of Molecular \& Clinical Medicine, 7(7), 5877. 
[44] Edna Maryani,AgusPurwanto,HayuKartika ,MochHaris,NurIhsan,KemasMuhammat

Abdul Fatah, Rudy Pramono (2020). DO GEMBA KAIZEN AND 5S REINFORCE MEDICAL

EQUIPMENT

MANUFACTURING PERFORMANCE ?.

European Journal of Molecular \& Clinical

Medicine, 7(7), 41-57.

[45] EnjiAzizi ， Sri NdaruArthawati , Sri Hastari , Muhammad RikzaMuqtada, Nur IhsanSaefulah, Agus Purwanto (2020). IMPACT OF GREEN LEADERSHIP AND ECO EFFICIENCY TOWARD WORK PERFORMANCE : EVIDENCE FROM INDONESIAN PUBLICT HEALTH CENTER. European Journal of Molecular \& Clinical Medicine, 7(7), 2840.

[46] AkhyarZuniawan, Sri MuktiWirawati, Saefulah , MochammadFahlevi , Agus Purwanto, Nico Alexander Vizano, Rudy Pramono (2020). Did SeiriSeitonSeisoSeiketsu And Shitsuke Affected Medical Health Industry Business Performance? European Journal of Molecular \& Clinical Medicine, 7(7), 97114.

[47] Fatoni ,Irawan, SuhrojiAdha , FairusSintawati, OctoberryJulyanto, Mukhlasin, RatihAyu Wulandari, Agus Purwanto (2020). Leadership Style For Indonesian Public Health Center: Charismatic,Bureaucratic,Transactional, Transformational,Autocratic Or Democratic?. European Journal of Molecular \& Clinical Medicine, 7(7), 115124.

[48] RizaPrimahendra TriAdiSumbogoReney Aquino Lensun, Agus Purwanto (2020). Handling Corona Virus Pandemic In The Indonesian Political Context: A Grounded Theory Study. European Journal of Molecular \& Clinical Medicine, 7(8), 113129.
[49] Desky, H., Mukhtasar, ., Istan, . M., Ariesa, . Y., Dewi, . I. B. M., Fahlevi, . M., Abdi, . M. N., Noviantoro, . R. \& Purwanto, . A. (2020) Did Trilogy Leadership Style, Organizational Citizenship Behaviour (OCB) and Organizational Commitment (OCO) Influence Financial Performance? Evidence from Pharmacy Industries. Systematic Reviews in Pharmacy, 11 (10), 297-305. doi:10.31838/srp.2020.10.50

[50] Sudibjo, N., \&Sutarji, T. (2020). The roles of job satisfaction, well-being, and emotional intelligence in enhancing the teachers' em- ployee engagements. Management Science Letters, 10, 24772482. https://doi.org/10.5267/j.msl.2020.4.002

[51] Sudibjo, N., \&Suwarli, M. B. N. (2020). Job Embeddedness and Job Satisfaction as a Mediator between Work-Life Balance and Intention to Stay. International Journal of Innovation, Creativity and Change, 11(8), 311-331.

[52] Vizano, N. A., Utami, . W., Johanes, . S., Herawati, . A., Aima, . H., Sutawijaya, . A. H., Purwanto, . A., Supono, . J., Rahayu, . P., Setiyani, . A. \&Widayati, . C. C. (2020) Effect of Compensation and Organization Commitment on Tournover Intention with Work Satisfaction as Intervening Variable in Indonesian Industries. Systematic Reviews in Pharmacy, 11 (9), 287-298. doi:10.31838/srp.2020.9.46

[53] Yunita Noor Azizaha, Muhammad KhairulRijalb, Rumainurc, UmiNuriyaturRohmahd, SyatriaAdymasPranajayae, ZulaechaNgiuf, Abdul Mufidg, Agus Purwantoh, Dahlia HaliahMa ui (2020) Transformational or Transactional Leadership Style: Which Affects Work Satisfaction and Performance of Islamic Business Lecturers During COVID-19 Pandemic?. 
Systematic Reviews in Pharmacy, 11 (7), 577-588. doi:10.31838/srp.2020.7.82

[54] Ardi, A., Djati, S. P., Bernarto, I., Sudibjo, N., Yulianeu, A., Nanda, H. A., \& Nanda, K. A. (2020a). The Relationship Between Digital Transformational Leadership Styles and Knowledge-Based Empowering Interaction for Increasing Organisational Innovativeness. International Journal of Innovation, Creativity and Change, 11(3), 259-277.

[55] Ardi, A., Djati, S. P., Bernarto, I., Sudibjo, N., Yulianeu, A., Nanda, H. A., \& Nanda, K. A. (2020b). The Secret to Enhancing Innovativeness in the Digital Industry. International Journal of Innovation, Creativity and Change, 12(12), 225-243.

[56] Mulyadi, Sudibjo, N., \& Bernarto, I. (2017). The Effect of Perceived Organizational Support, Work Engagement, and Job Satisfaction on Teacher's Performance at Xyz Middle and High School. International Journal of Economic Research, 14(13), 7-19.

[57] Vroom, V. H.,\&Yetton, P.W. (1973). Leadership and decision making. Pittsburgh, PA: University of Pittsburgh Press.

[58] Watson, A. J., Hatton, N. G., Squires, D. S., \& Soliman, I. K. (1991). School staffing and the quality of education: Teacheradjustment and satisfaction. Teaching and Teacher Education, 7, 6377.

[59] Yukl, G. (1994). Leadership in organizations (3rd ed.). Englewood Cliffs, NJ: Prentice Hall.

[60] Yukl, G. (1999). An evaluation of conceptual weaknesses in transformational and charismatic leadership theories. Leadership Quarterly, 10(2), 285-305.

[61]Zigarelli, M. (1996). An empirical test of conclusions from effective schools research. Journal of Educational Research, 90(2), 103-109. 